\title{
Towards Urban Conservation in The City of Solo, Indonesia
}

\author{
Putu Ayu P. Agustiananda \\ Department of Architecture, Islamic University of Indonesia \\ e-mail: agustiananda@staff.uii.ac.id
}

\begin{abstract}
This paper explains theoretical studies concerning urban heritage conservation. One of the frequently occurring problems in urban heritage is obsolescence. During the rapid process of urban development, regeneration of urban historic quarters is important in establishing and maintaining the character and identity of a city. This could be done by recovering the urban areas from obsolescence through renewal of the physical fabric as well as by revitalizing their economic life.

The city of Solo, Indonesia, provides an example how the Municipality through revitalization programs of several historic public open spaces has started some efforts concerning urban heritage conservation. Through the case studies, this papers tries to identify main problems faced by urban heritage of Solo especially by those historic public open spaces. It also intend to look at how the Municipality dealt with these problems through revitalization programs. It also tries to analyze several dimensions in urban conservation of both historic parks before and after the revitalization programs.

This paper concludes by addressing several lessons learned from the case studies, that substantial identified problems concerning conservation and socio-cultural aspects were resolved through revitalization programs. Despite the city's success in restoring their original function as public space as well as rehabilitating the decaying structures within the areas, some challenges still remain concerning the issues of authenticity and sustainability of the urban heritage.
\end{abstract}

Keywords: urban conservation, urban heritage, revitalization, historic public space

\section{Introduction}

The term heritage is used to represent a kind of legacy that has been bequeathed by the earlier generations to be passed on to the current and future generations. Ashworth and Turnbridge (1990:105 in Timothy and Boyd, 2003:3) define heritage as:

"The contemporary uses of the past... the interpretation of the past in history, the surviving relict building and artifacts and collective and individual memories are all harnessed in response to current needs which include the identification of individuals with social, ethnic and territorial entities and the provision of economic resources for commodification within heritage industries.”

Timothy and Boyd (2003) argue that the majority of heritage supply is urban in location. Urban heritage comprises not only individual buildings or monuments of historic interest, but also the physical attributes of buildings, public spaces and urban morphology (Orbaşli, 2000). The term 'heritage' acknowledges not only the non-economic values of the asset - in contrast with 'resources' which implies the consideration of its economic values - but also its bequest which further implies certain obligations and responsibilities (McKercher und du Cros, 2002). 


\section{From Monument Preservation To Urban Conservation}

The concept of conservation in many countries has developed in similar ways. At first, preservation policies were concerned with the "pastness" of the past, but afterwards, conservation and revitalization policies were about creating and maintaining "a future for the past" (Tiesdell, et.al, 1996). It developed from creating inventories of historic buildings to enacting legal frameworks for conservation of historic urban quarters.

At present, conservation is no longer considered a purely defensive activity (Breitling in Cain, 1981). The concept of conservation is more dynamic compared to that of preservation, since preservation is merely intended to maintain the historic building intact, while conservation aims at "strengthening unique character of the building as well as maintaining the harmony between the old environment and new development in accordance with public aspiration" (Reynolds, 1978, as quoted in Budihardjo, 1984).

\section{Obsolescence And Urban Conservation}

One of the frequently occurring problems in urban heritage is obsolescence. Obsolescence can be defined as diminished utility, the reduction in the useful life of a capital good (Tiesdell, et al, 1996). The phenomena of obsolescence on a city-wide scale demand the spatial rearrangement for improving relationship between areas and urban management is necessary to control the continuous change in the city (Thomas, 1996).

During the rapid process of urban development, regeneration of urban historic quarters is important in establishing and maintaining the character and identity of a city. This could be done by recovering the urban areas from obsolescence through renewal of the physical fabric as well as by revitalizing their economic life through utilization of historic buildings. According to Tiesdell, et al., (1996: 166), "the revitalization of historic urban quarters involves two processes which inevitably conflict: the rehabilitation of buildings and areas which seeks to accommodate the consequences of economic change and preservation which seeks to limit change and to protect the character of historic buildings and areas." Therefore, a compromise between both issues is required. The resolution should be based on the protection of the spirit of the place - the genius loci - as the most important feature of an historic urban area.

Physical conservation of historic property should be undertaken in accordance to conservation principles as indicated by some charters concerning cultural heritage, including the Burra Charter. The Burra Charter promotes a careful approach: "do as much as necessary to care for the place and 
to make it useable, but otherwise change it as little as possible so that its cultural significance is retained." Some physical conservation measures are known as: maintenance, preservation, restoration, reconstruction, and adaptation. These measures must be carried out with attention to the value of authenticity of the historic property. The degree and magnitude of permitted change and the implementation of controls in relation to the historic character of the quarter is therefore necessary. The control of change in such areas needs to be a negotiated process involving the reaching of consensus (Tiesdell, et al., 1996).

The broadened concept of conservation from individual building preservation to urban area revitalization and improvement requires integration to overall context of urban planning. The various aspects of planning like current and future land-uses, traffic circulation, as well as the demographic and social composition in such areas become involved in conservation issues (Ashworth and Turnbridge, 1990: p.15).

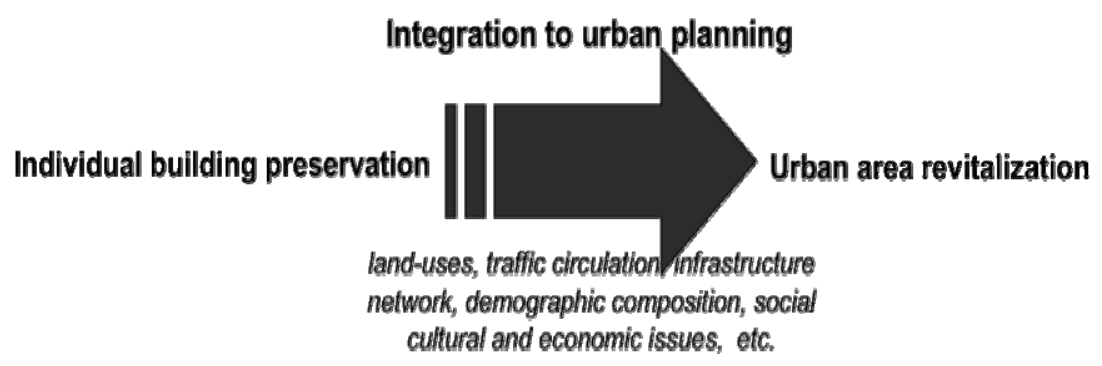

Figure 1. Broadened concept of conservation according Ashworth and Turnbridge (1990, p.15), summarized by Author

According to Orbaşli (2000), urban conservation has three dimensions that are interrelated and overlapped to each other. They are physical, spatial and social dimensions, which are encompassed within time as the fourth dimension. The characteristic of an urban conservation is not solitary, but rather multifaceted projects where many aspects and various parties are interconnected.

Table 1. Dimensions of urban conservation and their characteristics according to Orbaşli (2000), summarized by Author

\begin{tabular}{|l|l|}
\hline $\begin{array}{l}\text { Dimension } \\
\text { Physical } \\
\text { dimension }\end{array}$ & $\begin{array}{l}\text { Building conservation (covers projects involving old buildings, group of buildings, } \\
\text { new structures). the building fabric, the urban pattern, streets, open spaces, green } \\
\text { areas and urban vistas. }\end{array}$ \\
\hline $\begin{array}{l}\text { Spatial } \\
\text { dimension }\end{array}$ & $\begin{array}{l}\text { The urban planner's view of the city as a hole, including relationship between } \\
\text { spaces and their use, circulation and traffic, and the internal and external space } \\
\text { relationship. }\end{array}$ \\
\hline $\begin{array}{l}\text { Social } \\
\text { dimension }\end{array}$ & $\begin{array}{l}\text { Difficult to define, but the most important one, as continuity of conservation can } \\
\text { only be achieved through the continuation of urban life. }\end{array}$ \\
\hline
\end{tabular}




\section{Urban Conservation in The City of Solo, Indonesia}

Unlike those developed countries, Indonesia $\mathrm{n}$ as a developing country has not done very much on the field of urban conservation. Indeed, the conservation of historic sites in Indonesia is not a new issue. The significance of the conservation of cultural heritage has been recognized as early as 1931 in the Monumenten Ordonnantie Number 19 (Staatsblad Year 1931 No. 238). The law was then replaced by the Property Law of the Republic of Indonesia No.5 Year 1992 (UU No.5/1992). However, a legislation on urban conservation is still absent.

Like in other cities in most of developing countries, conservation issues have always been confronted with modern development. The rapid growth of population in big cities along with the extensive flow of urbanization continuously demands urgent developments and improvements, such as basic infrastructures provisions, housing, jobs, traffic and transportation improvement, and slum upgrading as priorities. These demands are so pressing that urban conservation still at its beginning. At present, those problems are also being experienced by Surakarta, which is popularly known as Solo, the second largest city in Central Java Province.

Based on completed heritage inventories carried out in 1989, the Surakarta Municipality passed the Mayor's Decree No. 646/116/I/1997 regarding historic buildings and areas of Surakarta in 1997. There are seventy historic buildings, monuments and urban sites that have cultural significance to the city listed in the Decree and are protected under Cultural Property Law. The cultural heritage is arranged into six categories (source: Decree of Mayor of Surakarta City No. 646/116/I/1997 regarding historic buildings and areas of Surakarta in 1997):

1) areas or districts

2) traditional buildings

3) colonial buildings

4) religious buildings

5) gates, memorials, bridges and street furniture

6) parks and public open spaces.

Nevertheless, the absence of regulations concerning the protection of the listed urban heritage has led to various problems. Conservation and social-cultural aspects were two among various problems identified in several urban heritage of Solo (Agustiananda, 2005):

a. Conservation aspect: vacant and decaying historic property

- Public property the problem might have resulted from the lack of concern or attempts to maintain those buildings and areas $\rightarrow$ also correlates with the lack of regular funding and incentive/disincentive schemes for conservation from the government or local authority.

- Failure or no serious attempts to find new uses for historic buildings and area 
b. Socio-cultural aspect: informal vendors in or near historic monuments and areas

- there are many illegal structures and informal vendors packed in or near the historic areas. This phenomenon is part of the excess of the economic crisis and social unrest of the city in 1998. Informal sectors were one of the worst hit economic sectors that caused many people to lose their jobs.

However, the condition became different when the new mayor was elected in 2006. Mr. Joko Widodo, with his vision and mission to reaffirm Solo as the City of Culture, the Municipality of Solo started to pay more attention to urban heritage. One of the main physical development program carried out by the Municipality is the revitalization of historic public space, which was designated as historic buildings and areas of Solo under category Parks and Public Open Spaces.

\section{Revitalization of Historic Park of Monumen ‘45 Banjarsari}

This park was once a field for battle training and horserace of the Mangkunegaran Aristocracy named Villa Park surrounded by residential neighborhood.

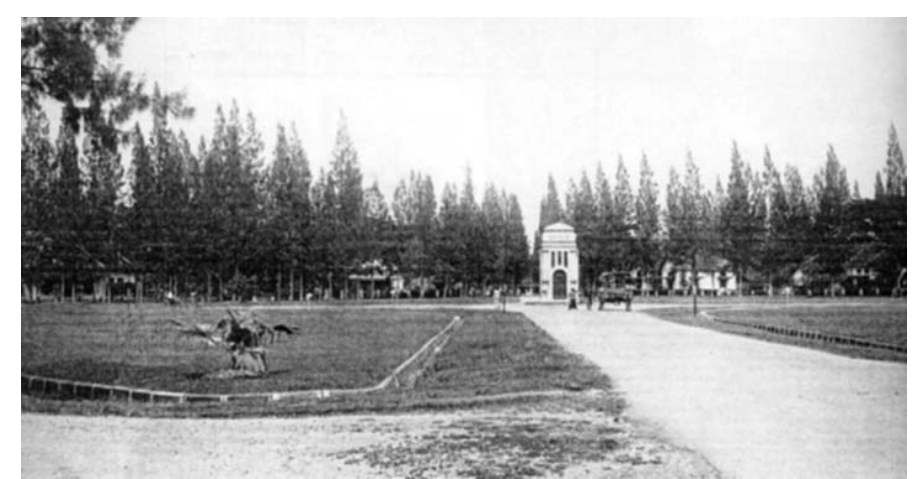

Figure 2. Villa Park, the initial park, circa 1900 (Bruggen and Wassing, 1998)

To commemorate the place where "the Four Day Battle" of the local with the Dutch in the 1945, a memorial was built in the area in 1976. Until before 1998, the park has become one of the favorite urban spaces. After the economic crisis hit Indonesia in 1998, informal vendors began to occupy the area.

To restore the park to its original function as urban green area, the Municipality started a revitalization program. This program was a great task in terms of coping with possible mass reactions as well as great budget required for compensation.

This program was completed in about eleven months, consisting various phases: inventory, new market design and construction development, public meetings, relocation process, and monument and park restoration. 
Through a persuasive and sensible approach, the Municipality finally succeeded in relocating 989 informal vendors to its newly built market through an attractive traditional transfer procession. The park itself was restored to its original function as public space for various activities like recreation, sports and flag ceremony.

The revitalization project consisted of: 1) maintenance and repair of the monument; 2) replanting of the vegetation; 3) rehabilitation of the street and pedestrian walkways; and 4) setting up of children playground. A comparative analysis of dimensions in urban conservation before and after the revitalization program of Balekambang Park is shown in table below.

Table 2. Analysis of dimensions in urban conservation before and after the revitalization program

\begin{tabular}{|c|c|c|}
\hline & Before & After \\
\hline 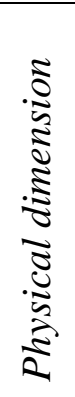 & $\begin{array}{l}\text { The informal vendors built temporary } \\
\text { shelters in the park. } \\
\text { Their 'kiosks' were made abruptly of used } \\
\text { building material, causing a chaotic view } \\
\text { as well as depletion of the physical } \\
\text { structures. } \\
\text { It had led to degrading environmental } \\
\text { condition in the area. }\end{array}$ & $\begin{array}{l}\text { The memorial was rehabilitated, } \\
\text { playgrounds and sports grounds were } \\
\text { built, plants and grass were replanted, and } \\
\text { infrastructures in the area were repaired. } \\
\text { The park was reborn, and once again it } \\
\text { turned out to be the favorite public space } \\
\text { in the city. }\end{array}$ \\
\hline 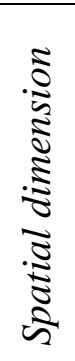 & $\begin{array}{l}\text { Informal marketplace created traffic and } \\
\text { circulation crowds. } \\
\text { The neighborhood's function as } \\
\text { residential area was disturbed and spatial } \\
\text { harmony within the district was damaged. }\end{array}$ & $\begin{array}{l}\text { Traffic and circulation was recovered and } \\
\text { internal and external space relationship } \\
\text { was improved. } \\
\text { The historic park regained its function as } \\
\text { public space that not only serves } \\
\text { surrounding residential neighborhood but } \\
\text { also becomes an urban landmark }\end{array}$ \\
\hline 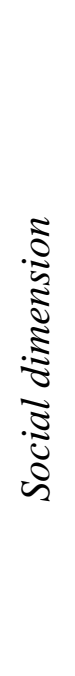 & $\begin{array}{l}\text { The area flowed down in the social } \\
\text { structure. The informal vendors who } \\
\text { illegally inhabited this area were marginal } \\
\text { community. } \\
\text { Before the project began, the Municipal } \\
\text { Agency for Informal Vendor Management } \\
\text { carried out an inventory. } \\
\text { Inventoried vendors were invited by the } \\
\text { municipality to a number of public } \\
\text { meetings to discuss about them and the } \\
\text { city's future. The forum finally decided on } \\
\text { the relocation as an indispensable } \\
\text { measure. }\end{array}$ & $\begin{array}{l}\text { - The municipality built a two-storey } \\
\text { market building for their relocation in the } \\
\text { urban periphery. } \\
\text { To support this relocation, the } \\
\text { municipality: } \\
\text { - improved transportation management } \\
\text { to ensure public accessibility to this } \\
\text { market. } \\
\text { - gave various facilities, including } \\
\text { permits and other required documents, } \\
\text { management training, investment } \\
\text { subsidies and bank loans. } \\
\text { Occupying a legal place, they obtained } \\
\text { guarantee for their business continuity. }\end{array}$ \\
\hline
\end{tabular}




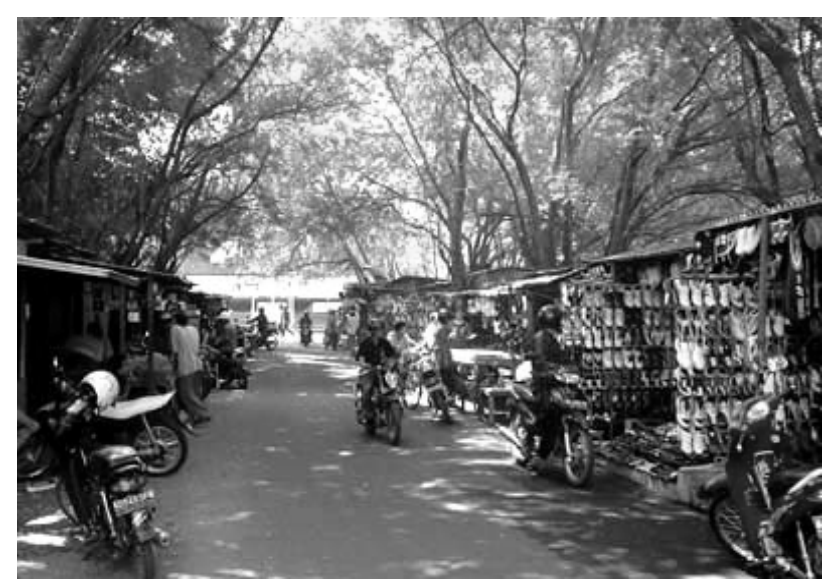

Figure 3. Monumen 45 Park (2005), before the revitalization program, crowded with informal vendors (Author's collection)

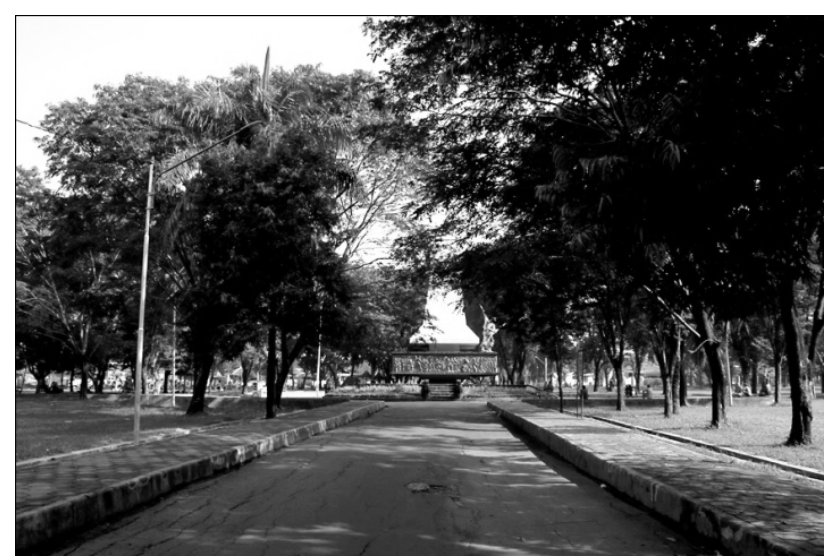

Figure 4. Monumen 45 Park at present, after the revitalization program (Author's collection)

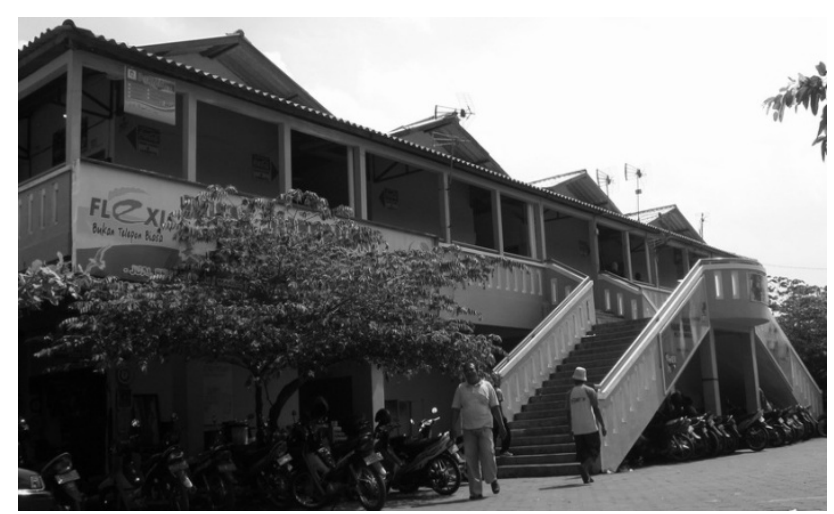

Figure 5. Pasar Klithikan Notoharjo, the market built to accommodate informal vendors postrelocation.

\section{Revitalization of Historic Park of Balekambang}

Partini Tuin, or popularly called Balekambang, was a public recreational park built by the Mangkunagaran VII by the end of 1921. In the vicinity there was also Partinah Bosch, a small manmade forest. Both green areas had various plants, including those of rare species, and became an important green open space of the city. 
A pond, along with a small wooden structure or shelter called bale, was built inside the Partini Tuin. From a distance, the bale looked as if it floated (kambang) in the pond. Therefore, the park derived its name Balekambang, the floating wooden shelter.

During the course of history, local drama kethoprak and traditional dances were frequently performed to the public park. Starting from 1970s, many people visited this park to see kethoprak performing. Then in 1987, Balekambang became more popular and reached its peak. However, afterward, its popularity fell down to its trough.

Considering its historic and cultural significance, the Municipality carried out a revitalization program for about a year from the preparatory, execution until finishing phases. The program was completed in 2008. A comparative analysis of dimensions in urban conservation before and after the revitalization program of Balekambang Park is shown in table below.

Table 3. Analysis of dimensions in urban conservation before and after the revitalization program

\begin{tabular}{|c|c|c|}
\hline & Before & After \\
\hline & 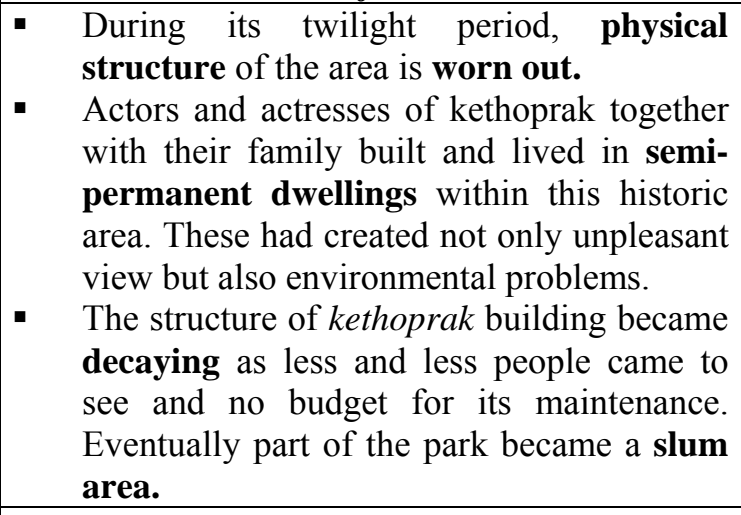 & $\begin{array}{l}\text { - During revitalization program, all decaying and } \\
\text { illicit structures in the area were torn down. } \\
\text { The park was replanted by a range of vegetation to } \\
\text { restore it as botanical garden, bearing an } \\
\text { ecological function as the city's air cleaner and } \\
\text { water/nature reserve. } \\
\text { To recreate Balekambang not only as nature } \\
\text { reserve but also as center for culture and arts, } \\
\text { several new structures, like a new building for art } \\
\text { performances and open-air theatre were built, and } \\
\text { some others construction projects, like art gallery } \\
\text { and workshop were planned to be built in the future. }\end{array}$ \\
\hline & $\begin{array}{l}\text { - When the area developed into a slum and } \\
\text { dilapidated neighborhood, this historic park } \\
\text { suffered from several functional problems. } \\
\text { There was discrepancy with its original } \\
\text { function as an historic green area that was } \\
\text { intended not only as bio-conservation area } \\
\text { but also a public space. } \\
\text { The failure in its functionality had certainly } \\
\text { made it an unproductive urban asset. }\end{array}$ & $\begin{array}{l}\text { - The revitalization program restored its function as } \\
\text { an urban green open space, and also improved its } \\
\text { circulation and accessibility. } \\
\text { Distance between buildings to be built within this } \\
\text { park is considerable, keeping low building ratio of } \\
\text { the area. } \\
\text { Based on the program master plan, the built area is } \\
\text { much smaller than the green open space } \rightarrow \\
\text { conforms to the building order. }\end{array}$ \\
\hline & $\begin{array}{l}\text { Like the case of Monumen } 45 \text { Park, } \\
\text { Balekambang flowed down in the social } \\
\text { structure. } \\
\text { People who inhabited semi-permanent } \\
\text { dwellings inside the complex lived in } \\
\text { limited infrastructures and services. } \\
\text { Within this deprived condition, a concealed } \\
\text { prostitution area started to develop in the } \\
\text { area. } \\
\text { These disadvantaged social and cultural } \\
\text { circumstances had contributed to the } \\
\text { declining image of the historic park. }\end{array}$ & $\begin{array}{l}\text { - The revitalization program has managed not only to } \\
\text { restore the park to a desired natural condition like } \\
\text { that of the past, but also to return its image as a } \\
\text { public space. } \\
\text { Ilegal structures were demolished and its inhabitants } \\
\text { were relocated in advance. Relocation for them } \\
\text { meant not only to make a better livelihood, but also } \\
\text { to improve their quality of life. }\end{array}$ \\
\hline
\end{tabular}




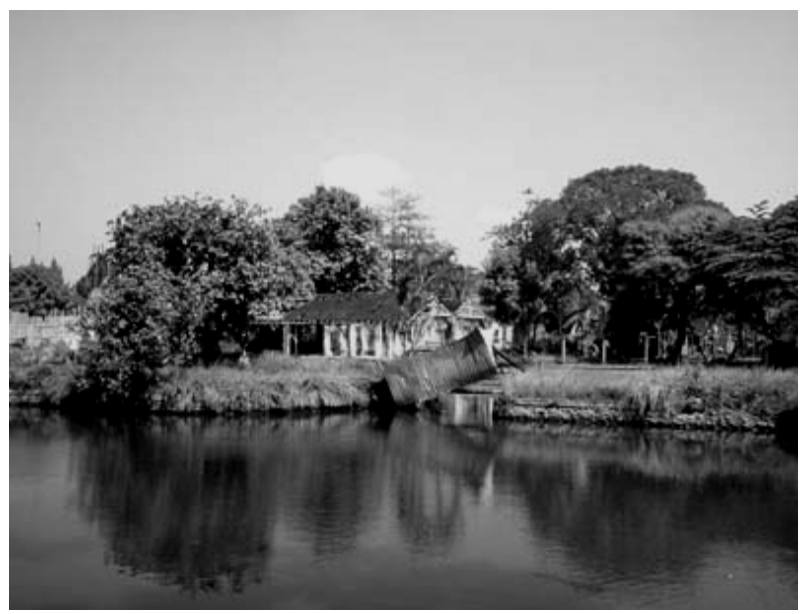

Figure 6. Balekambang Park (2005), before the revitalization program (Author's collection)

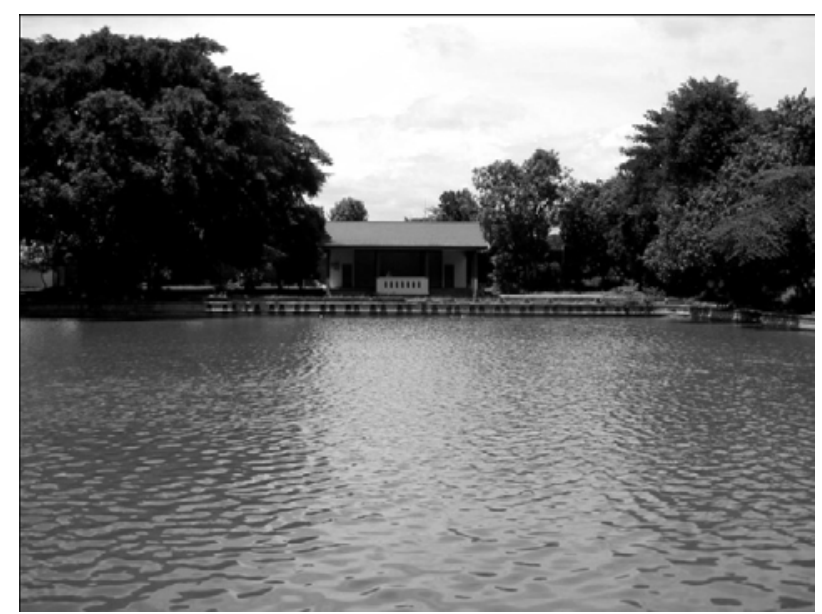

Figure 7. Balekambang Park at present after the revitalization program (Author's collection)

area or town. This could be achieved through urban regeneration, which recovers historic buildings and urban areas from obsolescence as well as revitalizes their economic life.

The city of Solo has demonstrated preliminary efforts in urban conservation through historic public spaces revitalization. In the case of Solo, substantial identified problems concerning conservation and socio-cultural aspects were resolved. Revitalization projects of both historic parks succeeded in restoring their original function as public space as well as in rehabilitating the decaying structures within the areas. The economic continuity of local community, including the informal vendors, was retained. The image of both parks has been brought back and became public green open space over again for the residents' leisure activities.

A compromise is necessary in dealing with the process of revitalization of historic urban areas as it involves conflicting issues, like preservation versus rehabilitation/restoration. The two case studies of historic urban space revitalization in Solo demonstrate that both opposing issues have not been treated in a balanced manner. Despite its success in physical rehabilitation, poor consideration was 
given to the authenticity of historic structures during the restoration projects of both public spaces. In fact, a particular attention should be given to this issue, so that the degree and magnitude of the permitted change and implementation of controls should be decided and applied in the urban revitalization.

Another challenge remains in urban heritage of Solo that revitalization programs intended to improve urban areas were carried out moderately by projects and not as comprehensive programs. Creation of special working group in each historic public space, consisting of officials of public institution, hired professionals as well as leaders of the local community is crucial in order to achieve sustainable heritage management. Above all, it is necessary for the Municipality of Solo to develop a legal framework for urban heritage conservation that is integrated to the overall urban planning.

\section{References}

Agustiananda, P. (2005). Cultural heritage and urban conservation in Indonesia, with a case study of Surakarta. Master's Thesis TU Cottbus, Germany.

Ashworth, G.J. and Turnbridge, J.E. (2000a). The tourist-historic city: retrospect and prospect of managing the heritage city. Amsterdam: Pergamon.

Bapeda Surakarta. (2003). Review Grand Design Kawasan Balekambang Surakarta. Surakarta: Bapeda Surakarta (Bidang Fisik Prasarana final report).

Breitling, P. (1981). The origins and development of a conservation philosophy in Austria. In: Kain, R., ed. Planning for conservation. London, Mansell, pp. 49-61.

Bruggen, van M.P and Wassing, R.S. (1998). Djokja en Solo: Beel van de Vorstensteden. Purmerend: Asia Maior.

Burra Charter -1996. [Online]. (URL http://www.icomos.org/burra_charter.html). 1988.

McKercher, B. and du Cros, H. (2002). Cultural tourism: the partnership between tourism and heritage management. New York: the Haworth Hospitality Press.

Orbaşli, A. (2000). Tourists in historic towns: urban conservation and heritage management. London: Spon.

Pemerintah Kodya Dati II Surakarta. (1993). Rencana Umum Tata Ruang Kota (RUTRK) Kotamadya Dati II Surakarta Tahun 1993-2013. (Urban Spatial Master Plan of the City of Surakarta Year 1993-2013).

--------- (1995). Inventarisasi bangunan dan kawasan kuno bersejarah di kotamadya daerah tingkat II Surakarta. Surakarta: Pemerintah Kodya Dati II Surakarta (Bappeda executive summary).

Pemerintah Kota Surakarta. (2007). Tabloid Pemkot Solo Berseri, Edisi II/2007. Solo: Badan Informasi dan Komunikasi Kota Surakarta.

(2006b). Tabloid Pemkot Solo Berseri, Edisi IX/2006. Solo: Badan Informasi dan Komunikasi Kota Surakarta. 
(2006a). Tabloid Pemkot Solo Berseri, Edisi I/2006. Solo: Badan Informasi dan Komunikasi Kota Surakarta.

Pickard, R.D. (1996). Conservation in the built environment. Essex: Longman.

Pickard, R., ed. (2001). Management of historic centres. London: Spon. (2001b). Policy and Law in Heritage Conservation. London: Spon.

Sidharta and Budihardjo, E. (1989). Konservasi lingkungan dan bangunan kuno bersejarah di Surakarta. Yogyakarta: Gadjah Mada University Press.

Thomas, M.J. (1996?). Conservation of the urban: issues and politics. Oxford: Oxford Brookes University. (School of Planning working paper no. 168).

Tiesdell, S., Oc, T. and Heath,T. (1996). Revitalizing historic urban quarters. Oxford: Architectural Press.

Timothy, D.J. and Boyd, S.W. (2003). Heritage Tourism. Harlow: Prentice Hall. 